\title{
Effect of Propofol on breast Cancer cell, the immune system, and patient outcome
}

\author{
Ru Li, Hengrui Liu, James P. Dilger and Jun Lin * (D)
}

\begin{abstract}
Breast cancer is the second leading cause of cancer death in women. Surgery is the first line of treatment for breast cancer. Retrospective clinical studies suggest that the type of anesthesia administered during oncological surgery may influence patient outcome. Propofol, the widely used intravenous anesthetic agent, may lead to better outcomes compared to volatile anesthetics. Here we review the literature on the effect of propofol in breast cancer cells, the immune system, pain management, and patient outcomes. Evidence from the study of breast cancer cell lines suggests that high concentrations of propofol have both anti-tumor and pro-tumor effects. Propofol and volatile anesthetics have different effects on the immune system. Propofol has also been shown to reduce the development and severity of acute and chronic pain following surgery. Although a retrospective study that included many types of cancer indicated that propofol increases the long-term survival of patients following surgery, the evidence for this in breast cancer is weak. It has been shown that Propofol combined with paravertebral block led to change of serum composition that affects the breast cancer cell behaviors and natural killer cell activity. Prospective studies are in progress and will be finished within 5 years. The existing evidence is not sufficient to warrant changes to current anesthetic management. Further research is needed to clarify the mechanisms by which propofol affects cancer cells and the immune system.
\end{abstract}

Keywords: Breast Cancer, Propofol, Proliferation, Migration, Natural killer cell

\section{Background}

Breast cancer is the most common malignancy in women, and the second leading cause of cancer mortality worldwide after lung cancer. In 2017, it is estimated that 252,710 women will be diagnosed with invasive breast cancer, and 40,610 women will die of breast cancer [1]. More than $90 \%$ of women diagnosed with early stage (I or II) breast cancer have mastectomy or breast-conserving surgery, and over $70 \%$ of women with advanced breast cancer (stage III or IV) have these surgeries [2]. Surgical resection of solid breast tumors is the primary and most effective treatment. However, local or metastatic recurrence after surgery does occur and is a major cause of cancer death. Localized and regionalized breast cancer patients have more than $80 \%$ 5-year survival rate, but breast cancer patients with distant organs only have $27 \% 5$-year survival rate [3]. In fact, the perioperative period presents many risks to patients. The process of surgery inevitably induces a profound

\footnotetext{
* Correspondence: jun.lin@stonybrookmedicine.edu Department of Anesthesiology, Stony Brook University Health Sciences Center, Stony Brook, NY 11794-8480, USA
}

stress response, which suppresses cell-mediated immunity, and enhances tumor growth and spread $[4,5]$. This is also a growing recognition that the anesthetics used during mastectomy may affect the long-term outcome.

Propofol is the most extensively used intravenous anesthetic for induction and maintenance of anesthesia in the United States. Volatile anesthetics such as isoflurane, sevoflurane and desflurane are also in common use. The two classes of anesthetics have different effects on immune function [6]. The choice of anesthetic used during cancer surgery may affect patient outcome. A recent retrospective study found significantly better long-term survival rates for patients receiving propofol (3714 patients, 504 deaths, 13.5\%), compared to patients receiving volatile anesthetics (3316 patients, 796 deaths, 24\%), following cancer surgery between 2010 and 2013 at a teaching hospital in the United Kingdom [7].

In this article, we review the effects of propofol on breast cancer cell biology, the immune system, and postoperative pain. We discuss recent retrospective studies and upcoming prospective studies on the influence of propofol on long-term outcomes of breast cancer

(c) The Author(s). 2018 Open Access This article is distributed under the terms of the Creative Commons Attribution 4.0 International License (http://creativecommons.org/licenses/by/4.0/), which permits unrestricted use, distribution, and 
patients. The literature in this review was obtained by searching PubMedఠ with search terms "propofol" and "breast cancer" on December 3, 2017, and limited to articles written in English.

\section{Effects of propofol on breast cancer cells}

Although we usually refer to breast cancer as a single disease, it includes up to 21 diverse histological subtypes, which respond distinctly to treatments and lead to various outcomes $[8,9]$. Based on the presence or absence of hormone receptors (estrogen receptor/ER, or progesterone receptor/PR), and excess levels of human epidermal growth factor receptor 2 (HER2+/HER2-), breast cancer is stratified into four major molecular subtypes, including luminal A (ER+ and/or PR+/HER2-), luminal $\mathrm{B}$ (ER+ and/or PR+/HER2+), HER2 overexpressing (ER-/ PR-/HER2+), and basal-like or triple negative (ER-/PR-/ HER2-) [10, 11]. To understand the biology of breast cancer, breast cancer cell lines have been established and widely used to investigate the effect of drugs on cancer cell proliferation, apoptosis, migration and invasion. To date, more than 51 breast cancer cell lines have been separated from primary tumor, and successfully cultured in vitro [12]. To mimic the heterogeneity of breast cancer, each molecular subtype mentioned above has several representatives. For instance, MCF7 is one of the most intensively studied cell lines from luminal A subtype. MDA-MB-468 and MDA-MB-231 both belong to triple negative breast cancer cell lines. MDA-MB-231 is further classified into a subgroup named "claudin-low" which signifies low gene expression of tight junction proteins claudin 3, 4, 7 and E-cadherin.

As the number of tumor surgeries performed under general anesthesia increases, the hypothesis that propofol has direct effects on cancer cells has become attractive. Indeed, a number of studies have shown that propofol influences the function of breast cancer cells and may do so via various cellular pathways.

\section{Anti-tumor effects}

Li et al. found that propofol $(2-10 \mu \mathrm{g} / \mathrm{mL})$ significantly suppressed migration and invasion of MDA-MB-231 cells [13]. They demonstrated that propofol reduced the expression and secretion of matrix metalloproteinase (MMP) -2 and -9. MMPs are thought to promote cancer cell invasion and metastasis by degrading extracellular matrix proteins. The effect of propofol may be due to attenuation of the phosphorylation of NF- $\mathrm{kB}$ and IKK. IKK is a kinase degrades IkB, which normally leads to $\mathrm{NF}-\mathrm{kB}$ activation. Thus, propofol interferes with NF- $\mathrm{KB}$ pathways in at least two ways.

Ecimovic et al. examined the effects of propofol (1-10 $\mu \mathrm{g} /$ $\mathrm{ml}$ ) on two breast cancer cell lines: MDA-MB-231 and MCF7, which are ER- and ER+ respectively. They found that propofol impaired migration but not proliferation of both cell lines. This was mediated by decreased expression of neuroepithelial cell transforming gene 1 (NET1) [14]. NET1 has also been associated with promotion of migration in adenocarcinoma in vitro [15].

A recent study showed that propofol downregulated miR-24 and increased p27 expression and cleaved caspase- 3 expression in MDA-MB-435 cells, all of which lead to induced cell death [16]. MDA-MB-435 is a cell line originated from a metastatic breast cancer but its origin could be melanoma instead [17].

Conjugation of fatty acids docosahexaenoic and eicosapentaenoic acid to propofol result in compounds that suppress cell adhesion, migration, and induce apoptosis more effectively than propofol itself. This was observed in several breast cancer cell lines MDA-MB-231, MCF-7 $\left(\mathrm{ER}^{+}\right)$AU565 $\left(\mathrm{Her}-2^{+}\right)$and MDA-MB-361 $\left(\mathrm{ER}^{+}, \mathrm{Her}-2^{+}\right)$ $[18,19]$. The fatty acids alone were not effective. The mechanism for this is not clear but may involve inhibition of histone deacetylase activity. It is also not known whether these propofol conjugates are anesthetics.

The in vitro studies described above presume that there is a direct effect of propofol on breast cancer cells. We summarized the potential mechanism of the direct anti-tumor effects of propofol in Fig. 1. Moreover, it is also possible that the effect of propofol is indirect. Several studies have used the serum from breast cancer patients who received one or another type of anesthesia. A group of patients was randomized to receive either propofol/paravertebral anesthesia-analgesia or sevoflurane general anesthesia with opioid analgesia. It should be noted that the addition of a paravertebral block with local anesthetics reduces the requirement of general anesthetics and opiates by blocking the afferent pain and sensory transmission, and suppressing the efferent sympathetic discharge that affect the immune function. Thus, it may be difficult to isolate the effects of propofol from those of the paravertebral block.

The first study examined proliferation and migration of MDA-MB-231 cells in the presence of $2-10 \%$ of serum obtained from patients $24-\mathrm{h}$ post-op. Cancer cell migration was not significantly affected by serum from patients receiving either propofol/paravertebral block or sevoflurane/opioid anesthesia. Incubation of cells with $10 \%$ serum from patients in the propofol/paravertebral group resulted in decreased viability compared to that from serum from patients receiving sevoflurane/opioid anesthesia. This decrease in viability is probably due to increased apoptosis [20].

In the second study, ER+/PR+ breast cancer cells (HCC1500) were co-cultured, for $24 \mathrm{~h}$, with nature killer (NK) cells obtained from healthy donors in the presence of serum from patients receiving either propofol/paravertebral or sevoflurane/opioid anesthesia. The serum 


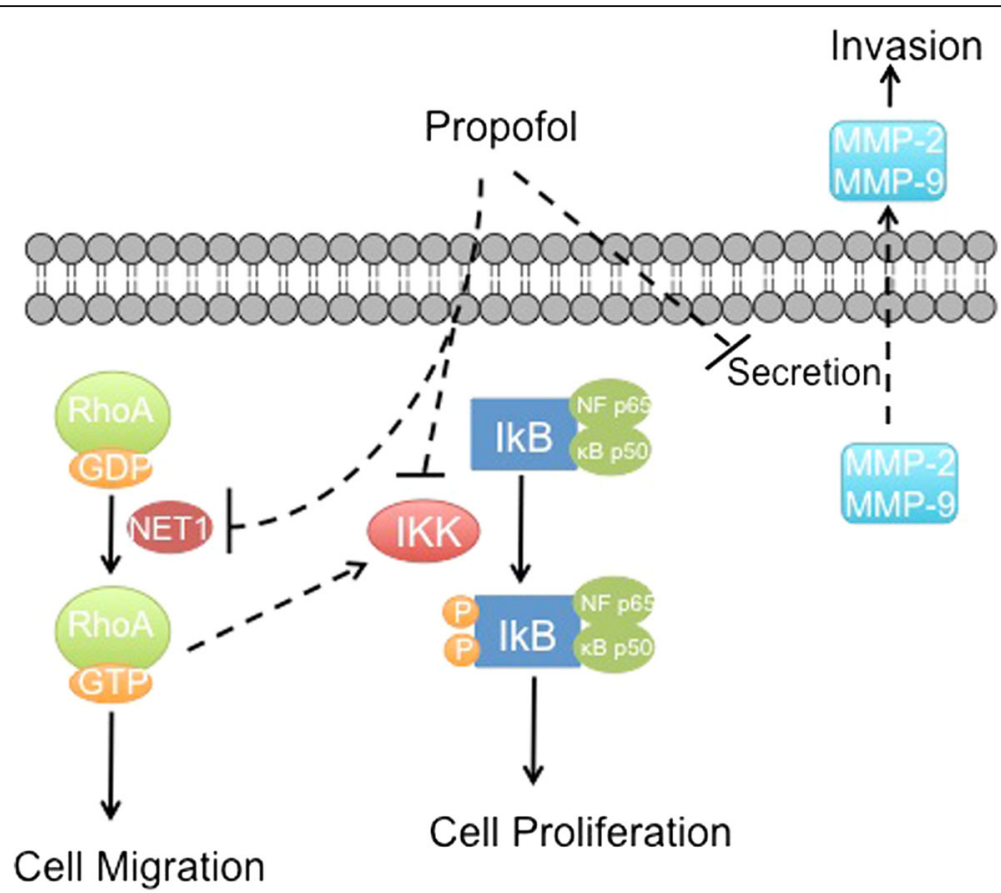

Fig. 1 Proposed mechanisms for the anti-tumor effects of propofol. Propofol impairs cell proliferation through inhibition of NF-kB pathway. It also reduces cell migration and invasion by inhibiting NET1, and decreasing the secretion of MMP2/MMP9

from the propofol/paravertebral group significantly induced apoptosis of HCC1500 cells, but the serum from sevoflurane/opioid group did not. Concomitantly, the serum from propofol/paravertebral patients increased the expression of the surface protein CD107a on NK cells without alteration of normal NK marker expression or secretion of cytokines [21]. CD107a is upregulated in stimulated NK cells and this correlates with NK cell-mediated lysis of target cells [22]. Serum from the sevoflurane patient reduced NK cell activating receptor CD16, IL-10, IL-1 $\beta$, all thus lowering the activity level of NK cells $[22,23]$.

\section{Pro-tumor effects}

In 2002, Garib et al. observed that propofol $(3-9 \mu \mathrm{g} / \mathrm{mL})$ increased migration of MDA-MB-468 cells [24]. They also found that propofol increased intracellular calcium and altered the organization of the actin cytoskeleton of these cells [25]. These effects of propofol were inhibited by the L-type calcium channel blocker verapamil. The group tested the hypothesis that propofol was acting via GABA-A receptor chloride channels. Although they found evidence for the gamma subunit of the GABA-A receptor and the effect of propofol was inhibited by the GABA-A antagonist bicuculline, they did not provide evidence for functional channels in the cells. It should be noted that bicuculline is not specific for GABA-A receptor channels; it is also known to block small conductance $\mathrm{Ca}^{++}$-activated $\mathrm{K}^{+}$channels at similar concentrations [26].

In a recent study, treatment of MDA-MB-231 cells with propofol $(2-10 \mu \mathrm{g} / \mathrm{mL})$ for up to $12 \mathrm{~h}$ was shown to increase cell proliferation and migration. The functional changes in the cells were correlated with an increase in nuclear factor E2-related factor-2 (Nrf2) expression level, and a decrease in p53 expression level, caspase-3 activity and percentage of apoptotic cells [27].

In summary, most studies conclude that propofol suppresses cancer cell viability and migration (Table 1). Some results are inconsistent with this though. The potential mechanism of pro-tumor effects is summarized in Fig. 2. One possible explanation for this discrepancy is the heterogeneity of breast cancer: propofol may have different actions on different cancer cell types. Another factor is non-standardization of experimental parameters such as the concentration and time of exposure to anesthetic. So far, there are few insights into the mechanism of action of propofol. Propofol has been identified to modulate HIF-1 $\alpha$ pathway in prostate cancer cells, which may shed light to the analysis of molecular mechanism of propofol in breast cancer [28]. Again, the heterogeneity of breast cancer may be obscuring a consistent mechanism for propofol. With the rapid advances in system biology, the mechanism of anesthetic-induced effects on cancer cells could be explored by using various "omics" technology. On the other hand, 
Table 1 Summary of the studies that examined direct effects of propofol on breast cancer cells

\begin{tabular}{|c|c|c|c|c|c|c|}
\hline Study & Cell line & $\begin{array}{l}\text { [Propofol] } \\
(\mu \mathrm{g} / \mathrm{ml})\end{array}$ & $\begin{array}{l}\text { Incubation } \\
\text { time (hr) }\end{array}$ & $\begin{array}{l}\text { Proliferation } \\
\text { (method) }\end{array}$ & Migration (method) & Invasion (method) \\
\hline Li et al & MDA-MB-231 & $2-10$ & 24 & & $\downarrow$ (wound healing) & $\downarrow$ (Matrigel membrane) \\
\hline $\begin{array}{l}\text { Ecimovic } \\
\text { et al }\end{array}$ & MDA-MB-231 & $6-10$ & 24 & $\begin{array}{l}\text { No change } \\
\text { (MTT) }\end{array}$ & $\downarrow$ (8 $\mu \mathrm{m}$ pores $)$ & No change (Matrigel membrane, $6 \mathrm{~h}$ ) \\
\hline $\begin{array}{l}\text { Ecimovic } \\
\text { et al }\end{array}$ & MCF7 & $4-10$ & 24 & $\begin{array}{l}\text { No change } \\
\text { (MTT) }\end{array}$ & $\downarrow$ (8 $\mu \mathrm{m}$ pores $)$ & $\downarrow$ (Matrigel membrane, 6 h) \\
\hline Yu et al & ${ }^{\mathrm{a}} \mathrm{MDA}-\mathrm{MB}-435$ & $2(10 \mu \mathrm{M})$ & 6 & $\downarrow$ (TUNEL stain) & & \\
\hline Siddiqui et al & MDA-MB-231 & $20(100 \mu \mathrm{M})$ & 24 & $\downarrow$ (WST-1) & $\begin{array}{l}\text { No change }(8 \mu \mathrm{m} \text { pores, } \\
4 \mathrm{~h}, 5 \mu \mathrm{g} / \mathrm{ml})\end{array}$ & \\
\hline Garib et al & MDA-MB-468 & $3-9$ & 10 & & $\uparrow$ (collagen matrix, video tracking) & \\
\hline Meng et al & MDA-MB-231 & $2-10$ & $12-24$ & $\uparrow(\mathrm{MTT}, 10 \mathrm{~h})$ & $\uparrow$ (wound healing) & \\
\hline
\end{tabular}

Note that propofol concentration and/or incubation time in a study may be different for different assays. This is noted in the Migration and Invasion columns ${ }^{a}$ MDA-MB-435 is a cell line originated from a metastatic breast cancer but its identity could be melanoma instead

cancer cell lines could only reflect part of the overall impact of propofol on cancer, as propofol may affect the progression of cancer in many other aspects.

One must use caution in interpreting the results of in vitro cell culture experiments. Most of the studies cited in this review used concentrations of propofol in the range of clinical doses (2 to $4 \mu \mathrm{g} / \mathrm{mL}$ [29-31]). However, propofol binds extensively to erythrocytes (50\%) and serum proteins almost exclusively albumin (48\%) [32]. As a result, cancer cells (and all other types of cells) in vivo are exposed to $<2 \%$ of the total propofol concentration. In contrast, the standard cell culture medium typically containing $10 \%$ fetal bovine serum used in in vitro experiments contains a much lower level of serum albumin (about 0.17 $\sim 0.34 \mathrm{~g} / \mathrm{dL}$ ) and negligible erythrocyte than that found in human plasma $(3.5 \sim 5.0 \mathrm{~g} / \mathrm{dL}$ albumin and abundant erythrocytes). Because of this, about $95 \%$ of the total propofol in a cell culture dish is free to bind to the cancer cells. Therefore, the free propofol concentration employed in the in vitro cell culture experiments may be 50-500 times that of the clinical concentrations. This would be a lethal dose for humans. Future in vitro experiments should be designed to take protein binding into account.

\section{Propofol and the immune system}

Surgical trauma is associated with an increase of cytokines and stress hormones in the plasma during the vulnerable peri-operative period [17]. This stress response

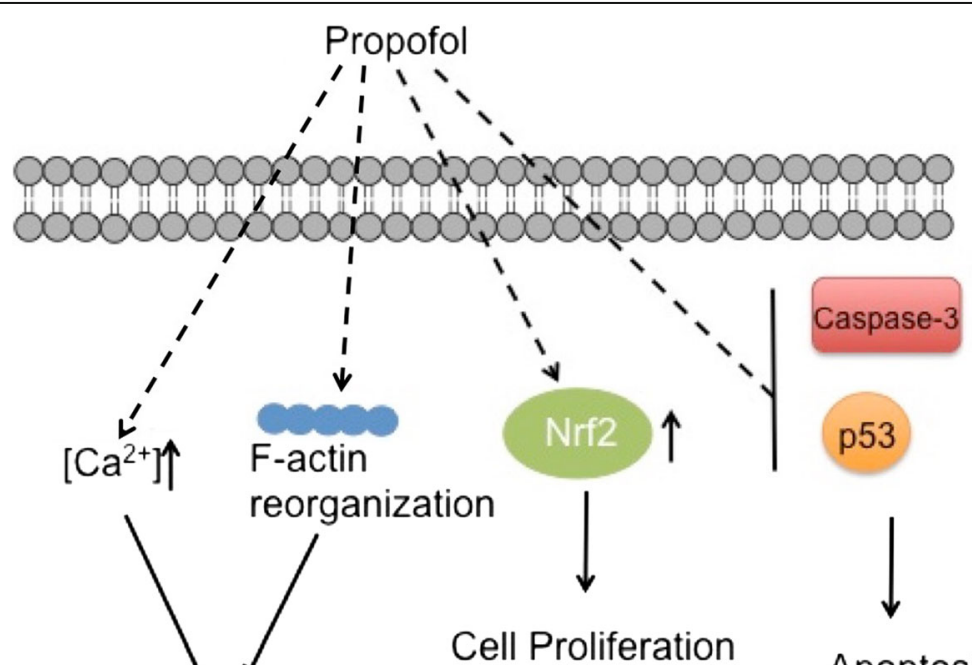

Apoptosis

\section{Cell Migration}

Fig. 2 Proposed mechanisms for the pro-tumor effects of propofol. Propofol enhances migration of breast cancer cells by increasing intracellular $\mathrm{Ca}^{2+}$ level and rearrangement of F-action. Propofol also promotes cell proliferation through Nrf2 pathway, and inhibits apoptosis by decreasing the expression of p53 and caspase-3 
induces transient suppression of cell-mediated immunity, the primary immune-defense against the invasion of tumor cells and micro-metastasis [33]. Surgery and anesthesia could suppress the immune response by activating the hypothalamic-pituitary-adrenal axis and the sympathetic nervous system [34]. Anesthetics may also directly affect the functions of immune cells, including natural killer (NK) cells, cytotoxic T cells, mononuclear cells and dendritic cells $[35,36]$. NK cells are large, granular cytotoxic lymphocytes that naturally recognize malignant cells, and induce lysis without prior sensitization. Low perioperative levels of NK activity are associated with an increased cancer related morbidity and mortality in humans [37]. Melamed and colleagues demonstrated in rats that ketamine, thiopental, and halothane but not propofol reduced the number of circulating NK cells and depressed NK cell cytotoxicity [38]. As discussed in the previous section, serum from patients who received sevoflurane/opioid anesthetics impaired NK cell induced lysis of breast cancer cells, while propofol-paravertebral anesthesia did not [21]. The same group also demonstrated that propofol-paravertebral anesthesia increased the infiltration of $\mathrm{NK}$ and $\mathrm{T}$ helper cells into breast cancer tissue [39]. A recent prospective randomized study measured the NK cell cytotoxicity in fifty patients $24 \mathrm{~h}$ after breast cancer surgery. Patients were randomly assigned to receive either propofol-remifentanil anesthesia with postoperative ketorolac analgesia or sevoflurane-remifentanil anesthesia with postoperative fentanyl analgesia. Propofol-ketorolac treatment increased NK cell cytotoxicity by $30 \%(p=0.048)$ compared to baseline whereas there was a $16 \%$ decrease in the sevoflurane-fentanyl group $(p=0.032)$ [40]. During stress conditions, the sympathetic nervous system releases catecholamines which suppress NK activity through $\beta$-adrenergic stimulation and therefore promote metastasis [41]. Propofol is known to interfere with $\beta$-adrenergic signal transduction in adipocytes [42]. Thus, the favorable impact of propofol on NK cells may be partially explained through the mechanism of $\beta$-adrenergic stimulation.

\section{Propofol and postoperative pain management}

Another risk factor associated with cancer surgery is postoperative acute and chronic pain. There is evidence that effective perioperative analgesia attenuates surgery-induced metastasis; this is likely due to a reduction in the stress response [43]. However, opioid-based analgesia has been implicated in potentiating tumor cell survival and angiogenesis [44], thus alternative strategies have been explored to limit the use of opioid. Two clinical studies have suggested that propofol may reduce the development and severity of both acute and chronic postoperative pain. The first retrospective study was conducted with 175 women 3 to 4 years after breast cancer surgery. Patients in the sevoflurane group $(n=$ 89 ) were more likely to have chronic pain $2 \sim 24$ months after surgery in comparison with propofol group $(n=86)$ $(p=0.007)$. Among patients with chronic pain from both groups, the choice of anesthetics made no difference in the severity or duration of the pain [45]. The second study prospectively randomized 66 patients scheduled for mastectomy to receive thoracic paravertebral blocks with either propofol-based total intravenous anesthesia or sham subcutaneous local anesthetic injections with sevoflurane-based general anesthesia. The paravertebral blocks with propofol significantly reduced the 6-mouth chronic neuropathic pain (CNP) risk according to the DN4 questionnaire, a screening tool, and the CNP grading system defined by International Association for the Study of Pain. The effect could be attributable to either the vertebral block, propofol or both [46].

\section{Propofol and clinical trials in breast cancer}

Three retrospective studies have compared propofol with volatile anesthetic agents on clinical outcomes of patients undergoing breast cancer surgery (Table 2). The first study, published in 2014 by Enlund and colleagues, reviewed surgical data from 1837 breast cancer patients with 620 in the propofol group and 1217 in the sevoflurane group. Differences in overall survival rates (propofol vs sevoflurane) for breast cancer were 3\% (95\% confidence interval, 1 to $4 \%, p<0.001$ ) at 1 year, and $2 \%$ ( -2 to $6 \%$, non-significant) at 5 years, in favor of propofol. However, the observed differences were eliminated after adjustment for confounders (history of cardiac ischemia was 1.8 times more likely in the sevoflurane group) [47]. The second study analyzed 325 patients with 173 in the propofol group and 152 in the sevoflurane group. No difference was observed in the overall 5-year survival rate between two groups, although the propofol group did have a lower rate of cancer recurrence $(p=0.037)$ [48]. The third study collected 2645 cases, which included 2589 in the volatile anesthesia group and 56 in the propofol group. There was no significant difference between the groups in terms of postoperative recurrence or survival probability [49]. Taken together, these studies suggest that propofol may either improve overall survival rates or lower the rate of cancer recurrence, but the evidence is not overwhelming. It is good to consider the limitations of these studies. First, there is the inherent limitation of retrospective studies in that they do not standardize clinical care and do not randomize patient groups. Therefore, the effects of confounding factors and selection bias cannot be easily eliminated. Second, one of the studies (Lee et al. [49]) had a relative small patient population and another (Kim et al. [50]) had an extremely uneven distribution between the two anesthetic groups. 
Table 2 Clinical trials comparing volatile anesthetics with propofol in breast cancer surgery

\begin{tabular}{|c|c|c|c|c|c|c|c|}
\hline Type of Study & Reference & Cancer & $\begin{array}{l}\text { Surgery } \\
\text { Type }\end{array}$ & $\begin{array}{l}\text { Anesthetic } \\
\text { Technique }\end{array}$ & Number of Patients & Outcome $(95 \% \mathrm{Cl})$ & $\begin{array}{l}\text { Estimated } \\
\text { Completion } \\
\text { Date }\end{array}$ \\
\hline Retrospective & Enlund et al. & Breast Cancer & $\begin{array}{l}\text { Breast cancer } \\
\text { surgery }\end{array}$ & $\begin{array}{l}\text { GA with propofol } \\
\text { or sevoflurane }\end{array}$ & $\begin{array}{l}1873 \text { (620 in propofol } \\
\text { and } 1217 \text { in } \\
\text { sevoflurane) }\end{array}$ & $\begin{array}{l}3 \% \text { higher for overall } \\
\text { survival at one year in } \\
\text { propofol group }(p<0.001)\end{array}$ & Finished \\
\hline Retrospective & Lee et al & Breast Cancer & $\begin{array}{l}\text { Modified } \\
\text { radical } \\
\text { mastectomy }\end{array}$ & $\begin{array}{l}\text { Propofol-based TIVA } \\
\text { or sevoflurane-based } \\
\text { anesthesia }\end{array}$ & $\begin{array}{l}325 \text { (173 in TIVA and } \\
152 \text { in sevoflurane) }\end{array}$ & $\begin{array}{l}\text { Propofol group showed } \\
\text { a lower rate of cancer } \\
\text { recurrence }(p=0.037)\end{array}$ & Finished \\
\hline Retrospective & Kim et al & Breast Cancer & $\begin{array}{l}\text { Breast } \\
\text { Cancer } \\
\text { surgery }\end{array}$ & $\begin{array}{l}\text { Propofol-based TIVA } \\
\text { or sevoflurane-based } \\
\text { anesthesia }\end{array}$ & $\begin{array}{l}2645 \text { (56 in TIVA and } \\
2589 \text { in volatile-base } \\
\text { anesthesia) }\end{array}$ & No difference & Finished \\
\hline Prospective & $\begin{array}{l}\text { University } \\
\text { of Zurich }\end{array}$ & Breast Cancer & $\begin{array}{l}\text { Breast } \\
\text { Cancer } \\
\text { surgery }\end{array}$ & $\begin{array}{l}\text { GA with propofol } \\
\text { TCI or sevoflurane }\end{array}$ & 231 & $\begin{array}{l}\text { Circulating tumor cells } \\
\text { at } 3 \text { days after surgery }\end{array}$ & $\begin{array}{l}\text { August, } \\
2017\end{array}$ \\
\hline Prospective & $\begin{array}{l}\text { Konkuk } \\
\text { University } \\
\text { Medical Center }\end{array}$ & Breast Cancer & $\begin{array}{l}\text { Breast } \\
\text { Cancer } \\
\text { surgery }\end{array}$ & $\begin{array}{l}\text { GA with propofol } \\
\text { or sevoflurane }\end{array}$ & 300 & $\begin{array}{l}\text { NK cell activity at } 1 \text { and } \\
24 \mathrm{~h} \text { after surgery }\end{array}$ & July, 2020 \\
\hline Prospective & $\begin{array}{l}\text { Uppsala } \\
\text { University }\end{array}$ & $\begin{array}{l}\text { Breast, colonic } \\
\text { and rectal } \\
\text { cancer }\end{array}$ & $\begin{array}{l}\text { Breast } \\
\text { Cancer } \\
\text { surgery }\end{array}$ & $\begin{array}{l}\text { GA with propofol } \\
\text { or sevoflurane }\end{array}$ & 2000 & Overall 5-year survival & $\begin{array}{l}\text { December, } \\
2022\end{array}$ \\
\hline
\end{tabular}

GA general anesthesia, TIVA total intravenous anesthesia, $T C I$ target-controlled infusion, $N K$ cell natural killer cell

To obtain hard evidence of a causal relationship between anesthetics and cancer outcomes, prospective randomized controlled trials are needed. There are six current prospective randomized clinical trials registered on databases worldwide comparing volatile anesthetics to propofol anesthesia [50]. Three of them specifically focus on or include breast cancers (Table 2). The first study is analyzing the number of circulating tumors cells at 3 days after surgery [51]. The primary outcome of the second study is NK cell activity at 1 and $24 \mathrm{~h}$ after surgery [52]. Those two studies may further provide translational evidence on mechanism of propofol on cancer outcome. In the third study, the primary endpoint is the 5 -year survival rate [53]. All three studies compare the volatile anesthetic sevoflurane with propofol.

\section{Conclusion}

For many years, the relationship between anesthetic techniques and cancer outcomes has captured interest in oncological surgery. The current literature suggests that the choice of anesthetic is correlated with cancer patient survival or recurrence after surgery with propofol considered beneficial compared to volatile anesthetics. The potential benefits of propofol might include impairment of cancer cell functions, preservation of immune function and reduction in surgical stress. However, the existing laboratory studies and clinical trials including propofol are inconsistent and inconclusive. Most in vitro studies focus on the analysis of changes in cancer cell behavior in response to propofol but do not delve deeply into potential mechanism. The beneficial effects of propofol on immune system are largely restricted to NK cells. Moreover, most clinical studies are retrospective, which are not sufficient to recommend changes in anesthesia practice. Hopefully the ongoing prospective clinical trials may offer a more definite answer. In the meantime, additional studies are required to help unravel the role anesthetics in the immune function using animal models, and explore potential therapy to counteract the dentrimental effect of certain anesthetics. In terms of direct effect of propofol on cancer cell, protein/ gene targets are necessary to decipher the molecular mechanism, particularly with respect to the heterogeneity of breast cancer. Additional in vivo and in vitro studies are urgently needed to improve our current clinical guidance.

\begin{abstract}
Abbreviations
CNP: Chronic neuropathic pain; ER: Estrogen receptor; GA: General anesthesia; GABA-A: Type A gamma-aminobutyric acid receptor; HER2: Human epidermal growth factor receptor 2; HIF-1a: hypoxia-inducible factor-1 alpha; IKK: I kappa B kinase; MMP: Matrix metalloproteinase; NET1: Neuroepithelial cell transforming gene 1; NF- kB: Nuclear factor kappalight -chain-enhancer of activated B cells; NK cell: Nature killer cell; Nrf2: E2related factor-2; PR: Progesterone receptor; TCl: Target-controlled infusion; TIVA: Total intravenous anesthesia
\end{abstract}

\section{Funding}

This work was supported by grant from Research Fund of Department of Anesthesiology in Stony Brook University.

Availability of data and materials

All data generated or analyzed during this study are included in this published article.

\section{Authors' contributions}

$\mathrm{RL}$ and $\mathrm{HL}$ contributed equally to the literature review and draft preparation of the manuscript. JPD helped with manuscript editing, and modifying figures and Tables. JL contributed to the writing, review and editing of the manuscript. All authors read and approved the final manuscript. 


\section{Ethics approval and consent to participate}

No Applicable

\section{Consent for publication}

Not Applicable

\section{Competing interests}

Dr. Jun Lin is the section editor of "General pharmacology and pharmacokinetic" of BMC Anesthesiology. Dr. James P. Dilger is an associate editor of BMC Anesthesiology.

\section{Publisher's Note}

Springer Nature remains neutral with regard to jurisdictional claims in published maps and institutional affiliations.

\section{Received: 11 January 2018 Accepted: 11 June 2018}

Published online: 26 June 2018

\section{References}

1. American Cancer Society. Cancer Facts \& Figures 2017. Atlanta: American Cancer Society; 2017. https://www.cancer.org/content/dam/cancer-org/ research/cancer-facts-and-statistics/annual-cancer-facts-and-figures/2017/ cancer-facts-and-figures-2017.pdf. Accessed 20 June 2018.

2. DeSantis CE, Lin CC, Mariotto AB, Siegel RL, Stein KD, Kramer JL, Alteri R, Robbins AS, Jemal A. Cancer treatment and survivorship statistics, 2014. CA Cancer J Clin. 2014;64(4):252-71.

3. Rafferty EA, Park JM, Philpotts LE, Poplack SP, Sumkin JH, Halpern EF, Niklason LT. Assessing radiologist performance using combined digital mammography and breast tomosynthesis compared with digital mammography alone: results of a multicenter, multireader trial. Radiology. 2013;266(1):104-13.

4. Al-Sahaf $\mathrm{O}$, Wang JH, Browne TJ, Cotter TG, Redmond HP. Surgical injury enhances the expression of genes that mediate breast cancer metastasis to the lung. Ann Surg. 2010;252(6):1037-43.

5. Gottschalk A, Sharma S, Ford J, Durieux ME, Tiouririne M. Review article: the role of the perioperative period in recurrence after cancer surgery. Anesth Analg. 2010;110(6):1636-43.

6. Homburger JA, Meiler SE. Anesthesia drugs, immunity, and long-term outcome. Curr Opin Anaesthesiol. 2006;19(4):423-8.

7. Wigmore TJ, Mohammed K, Jhanji S. Long-term survival for patients undergoing volatile versus IV anesthesia for Cancer surgery: a retrospective analysis. Anesthesiology. 2016;124(1):69-79.

8. Dieci MV, Orvieto E, Dominici M, Conte P, Guarneri V. Rare breast cancer subtypes: histological, molecular, and clinical peculiarities. Oncologist. 2014; 19(8):805-13.

9. Yang XR, Chang-Claude J, Goode EL, Couch FJ, Nevanlinna H, Milne RL, Gaudet M, Schmidt MK, Broeks A, Cox A, et al. Associations of breast cancer risk factors with tumor subtypes: a pooled analysis from the breast Cancer association consortium studies. J Natl Cancer Inst. 2011;103(3):250-63.

10. Perou CM, Sorlie T, Eisen MB, van de Rijn M, Jeffrey SS, Rees CA, Pollack JR, Ross DT, Johnsen H, Akslen LA, et al. Molecular portraits of human breast tumours. Nature. 2000;406(6797):747-52.

11. Network CGA. Comprehensive molecular portraits of human breast tumours. Nature. 2012;490(7418):61-70.

12. Neve RM, Chin K, Fridlyand J, Yeh J, Baehner FL, Fevr T, Clark L, Bayani N, Coppe J-P, Tong F, et al. A collection of breast cancer cell lines for the study of functionally distinct cancer subtypes. Cancer Cell. 2006:10(6):515-27.

13. Li Q, Zhang L, Han Y, Jiang Z, Wang Q. Propofol reduces MMPs expression by inhibiting NF-kappaB activity in human MDA-MB-231 cells. Biomed Pharmacother. 2012;66(1):52-6.

14. Ecimovic P, Murray D, Doran P, Buggy DJ. Propofol and bupivacaine in breast cancer cell function in vitro - role of the NET1 gene. Anticancer Res. 2014;34(3):1321-31.

15. Murray D, Horgan G, MacMathuna P, Doran P. NET1-mediated RhoA activation facilitates lysophosphatidic acid-induced cell migration and invasion in gastric cancer. Br J Cancer. 2008;99(8):1322-9.

16. Yu B, Gao W, Zhou H, Miao X, Chang Y, Wang L, Xu M, Ni G. Propofol induces apoptosis of breast cancer cells by downregulation of miR-24 signal pathway. Cancer Biomark. 2017;21(3):513-19.
17. Goldfarb Y, Ben-Eliyahu S. Surgery as a risk factor for breast cancer recurrence and metastasis: mediating mechanisms and clinical prophylactic approaches. Breast Dis. 2006;26:99-114.

18. Siddiqui RA, Zerouga M, Wu M, Castillo A, Harvey K, Zaloga GP, Stillwell W. Anticancer properties of propofol-docosahexaenoate and propofol-eicosapentaenoate on breast cancer cells. Breast Cancer Res. 2005;7(5):R645

19. Harvey KA, Xu Z, Whitley P, Davisson VJ, Siddiqui RA. Characterization of anticancer properties of 2,6-diisopropylphenol-docosahexaenoate and analogues in breast cancer cells. Bioorg Med Chem. 2010;18(5):1866-74.

20. Jaura Al, Flood G, Gallagher HC, Buggy DJ. Differential effects of serum from patients administered distinct anaesthetic techniques on apoptosis in breast cancer cells in vitro: a pilot study. Br J Anaesth. 2014;113(Suppl 1):i63-7.

21. Buckley A, McQuaid S, Johnson P, Buggy DJ. Effect of anaesthetic technique on the natural killer cell anti-tumour activity of serum from women undergoing breast cancer surgery: a pilot study. Br J Anaesth. 2014;113:56-62.

22. Alter G, Malenfant JM, Altfeld M. CD107a as a functional marker for the identification of natural killer cell activity. J Immunol Methods. 2004 294(1-2):15-22

23. Deegan CA, Murray D, Doran P, Moriarty DC, Sessler DI, Mascha E, Kavanagh $\mathrm{BP}$, Buggy DJ. Anesthetic technique and the cytokine and matrix metalloproteinase response to primary breast cancer surgery. Reg Anesth Pain Med. 2010;35(6):490-5.

24. Garib V, Niggemann B, Zänker KS, Brandt L, Kubens BS. Influence of nonvolatile anesthetics on the migration behavior of the human breast cancer cell line MDA-MB-468. Acta Anaesthesiol Scand. 2002:46(7):836-44.

25. Garib V, Lang K, Niggemann B, Zanker KS, Brandt L, Dittmar T. Propofolinduced calcium signalling and actin reorganization within breast carcinoma cells. Eur J Anaesthesiol. 2005;22(8):609-15.

26. Khawaled R, Bruening-Wright A, Adelman JP, Maylie J. Bicuculline block of small-conductance calcium-activated potassium channels. Pflugers Arch. 1999:438(3):314-21.

27. Meng C, Song L, Wang J, Li D, Liu Y, Cui X. Propofol induces proliferation partially via downregulation of p53 protein and promotes migration via activation of the Nrf2 pathway in human breast cancer cell line MDA-MB231. Oncol Rep. 2017:37(2):841-8.

28. Huang H, Benzonana LL, Zhao H, Watts HR, Perry NJ, Bevan C, Brown R, Ma D. Prostate cancer cell malignancy via modulation of HIF-1alpha pathway with isoflurane and propofol alone and in combination. Br J Cancer. 2014 111(7):1338-49

29. Fu F, Chen X, Feng Y, Shen Y, Feng Z, Bein B. Propofol EC50 for inducing loss of consciousness is lower in the luteal phase of the menstrual cycle. $\mathrm{Br}$ J Anaesth. 2014:112(3):506-13.

30. Hammer GB, Litalien C, Wellis V, Drover DR. Determination of the median effective concentration (EC50) of propofol during oesophagogastroduodenoscopy in children. Paediatr Anaesth. 2001;11(5):549-53.

31. Li S, Yu F, Zhu H, Yang Y, Yang L, Lian J. The median effective concentration (EC50) of propofol with different doses of fentanyl during colonoscopy in elderly patients. BMC Anesthesiol. 2016:16:24

32. Mazoit JX, Samii K. Binding of propofol to blood components: implications for pharmacokinetics and for pharmacodynamics. Br J Clin Pharmacol. 1999; 47:35-42.

33. Smyth MJ, Godfrey DI, Trapani JA. A fresh look at tumor immunosurveillance and immunotherapy. Nat Immunol. 2001;2:293-9.

34. Udelsman R, Norton JA, Jelenich SE, Goldstein DS, Linehan WM, Loriaux DL, Chrousos GP. Responses of the hypothalamic-pituitary-adrenal and reninangiotensin axes and the sympathetic system during controlled surgical and anesthetic stress. J Clin Endocrinolo Metab. 1987:64(5):986-94.

35. Kelbel I, Weiss M. Anaesthetics and immune function. Curr Opin Anaesthesiol. 2001:14:685-91.

36. Brand JM, Fau KH, Fau PC, Schmucker P. The effects of general anesthesia on human peripheral immune cell distribution and cytokine production. Clin Immunol Immunopathol. 1997;82:190-4.

37. Wu J, Lanier LL. Natural killer cells and cancer. Adv Cancer Res. 2003:90:127-56.

38. Melamed R, Bar-Yosef S Fau - Shakhar G, Shakhar G Fau, Shakhar K, Shakhar K Fau - Ben-Eliyahu S, Suppression of natural killer cell activity and promotion of tumor metastasis by ketamine, thiopental, and halothane, but not by propofol: mediating mechanisms and prophylactic measures. Anesth Analg 2003, 97:1331-1339.

39. Desmond F, McCormack J, Mulligan N, Stokes M, Buggy DJ. Effect of anaesthetic technique on immune cell infiltration in breast cancer: a follow- 
up pilot analysis of a prospective, randomised, investigator-masked study. Anticancer Res. 2015;35(3):1311-9.

40. Cho JS, Lee MH, Kim SI, Park S, Park HS, Oh E, Lee JH, Koo BN. The effects of perioperative anesthesia and analgesia on immune function in patients undergoing breast Cancer resection: a prospective randomized study. Int J Med Sci. 2017;14(10):970-6.

41. Shakhar G, Ben-Eliyahu S. In Vivo $\beta$-Adrenergic Stimulation Suppresses Natural Killer Activity and Compromises Resistance to Tumor Metastasis in Rats. J Immunol. 1998;160(7):3251.

42. Kurokawa MDH, Murray PDPaul A, Damron PDDerek S. Propofol attenuates $\beta$-Adrenoreceptor-mediated signal transduction via a protein kinase Cdependent pathway in Cardiomyocytes. Anesthesiology. 2002;96(3):688-98.

43. Page GG, Blakely WP, Ben-Eliyahu S. Evidence that postoperative pain is a mediator of the tumor-promoting effects of surgery in rats. Pain. 2001;90(1-2): $191-9$.

44. Juneja R. Opioids and cancer recurrence. Current Opin Support Palliat Care. 2014;8(2):91-101.

45. Cho AR, Kwon JY, Kim KH, Lee HJ, Kim HK, Kim ES, Hong JM, Kim C. The effects of anesthetics on chronic pain after breast cancer surgery. Anesth Analg. 2013;116(3):685-93.

46. Abdallah FW, Morgan PJ, Cil T, Escallon JM, Semple JL, Chan WW. Comparing the DN4 tool with the IASP grading system for chronic neuropathic pain screening after breast tumor resection with and without paravertebral blocks: a prospective 6-month validation study. Pain. 2015;156(4):740-9.

47. Enlund M, Berglund A, Andreasson K, Cicek C, Enlund A, Bergkvist L. The choice of anaesthetic-sevoflurane or propofol-and outcome from cancer surgery: a retrospective analysis. Ups J Med Sci. 2014;119(3):251-61.

48. Lee JH, Kang SH, Kim Y, Kim HA, Kim BS. Effects of propofol-based total intravenous anesthesia on recurrence and overall survival in patients after modified radical mastectomy: a retrospective study. Korean J Anesthesiol. 2016;69(2):126-32.

49. Kim MH, Kim DW, Kim JH, Lee KY, Park S, Yoo YC. Does the type of anesthesia really affect the recurrence-free survival after breast cancer surgery? Oncotarget. 2017;8(52):90477-87.

50. Royds J, Khan AH, Buggy DJ. An update on existing ongoing prospective trials evaluating the effect of anesthetic and analgesic techniques during primary Cancer surgery on Cancer recurrence or metastasis. Int Anesthesiol Clin. 2016;54(4):e76-83.

51. Subramani S, Poopalalingam R. Bonfils assisted double lumen endobronchial tube placement in an anticipated difficult airway. J Anaesthesiol Clin Pharmacol. 2014;30(4):568-70.

52. Weng $H, X u Z Y$, Liu J, Ma D, Liu DS. Placement of the Univent tube without fiberoptic bronchoscope assistance. Anesth Analg. 2010;110(2):508-14.

53. Schuepbach R, Grande B, Camen G, Schmidt AR, Fischer H, Sessler DI, Seifert B, Spahn DR, Ruetzler K. Intubation with VivaSight or conventional left-sided double-lumen tubes: a randomized trial. Can J Anaesth. 2015;62(7):762-9.

\section{Ready to submit your research? Choose BMC and benefit from:}

- fast, convenient online submission

- thorough peer review by experienced researchers in your field

- rapid publication on acceptance

- support for research data, including large and complex data types

- gold Open Access which fosters wider collaboration and increased citations - maximum visibility for your research: over $100 \mathrm{M}$ website views per year

At BMC, research is always in progress.

Learn more biomedcentral.com/submissions 